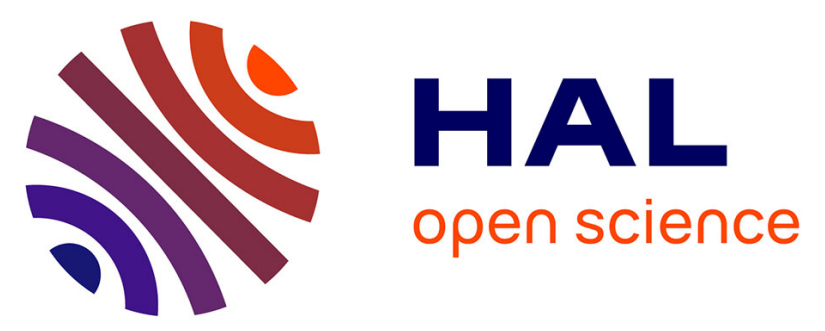

\title{
Investigating the respective impacts of groundwater exploitation and climate change on wetland extension over 150 years
}

\author{
Antoine Armandine Les Landes, Luc Aquilina, Jo de Ridder, Laurent \\ Longuevergne, Christian Pagé, Pascal Goderniaux
}

\section{To cite this version:}

Antoine Armandine Les Landes, Luc Aquilina, Jo de Ridder, Laurent Longuevergne, Christian Pagé, et al.. Investigating the respective impacts of groundwater exploitation and climate change on wetland extension over 150 years. Journal of Hydrology, 2014, 509, pp.367-378. 10.1016/j.jhydrol.2013.11.039 . insu-00920690

\section{HAL Id: insu-00920690 \\ https://hal-insu.archives-ouvertes.fr/insu-00920690}

Submitted on 9 Jan 2014

HAL is a multi-disciplinary open access archive for the deposit and dissemination of scientific research documents, whether they are published or not. The documents may come from teaching and research institutions in France or abroad, or from public or private research centers.
L'archive ouverte pluridisciplinaire HAL, est destinée au dépôt et à la diffusion de documents scientifiques de niveau recherche, publiés ou non, émanant des établissements d'enseignement et de recherche français ou étrangers, des laboratoires publics ou privés. 


\title{
Investigating the respective impacts of groundwater exploitation
}

\author{
and climate change on wetland extension over 150 years
}

Manuscript prepared for submission to Journal of Hydrology - March 2012

First submission - December 2012

Antoine ARMANDINE LES LANDES ${ }^{1 *}$, Luc AQUILINA ${ }^{1}$, Jo DE RIDDER ${ }^{1}$, Laurent LONGUEVERGNE ${ }^{1}$, Christian PAGÉ ${ }^{2}$, Pascal GODERNIAUX ${ }^{1,3}$.

${ }^{1}$ Geosciences Rennes - CNRS - UMR 6118

University of Rennes 1

Bâtiment 14B

Campus Beaulieu

263 Avenue du Général Leclerc

35042 Rennes

France

*antoine.armandineleslandes@univ-rennes1.fr

(+33) 223236624

luc.aquilina@univ-rennes1.fr

laurent.longuevergne@univ-rennes1.fr

${ }^{2}$ European Center for Research and Advanced Training in Scientific Computing

42, avenue Gaspard Coriolis

Toulouse F-31057 Cedex 1

France

christian.page@cerfacs.fr

${ }^{3}$ Geology and Applied Geology

University of Mons

9, Rue de Houdain

B-7000 Mons

Belgium

Pascal.GODERNIAUX@umons.ac.be

*Corresponding author 


\section{Abstract}

2 Peatlands are complex ecosystems driven by many physical, chemical, and biological

3 processes. Peat soils have a significant impact on water quality, ecosystem productivity and

4 greenhouse gas emissions. However, the extent of peatlands is decreasing across the world,

5 mainly because of anthropogenic activities such as drainage for agriculture or groundwater

6 abstractions in underlying aquifers. Potential changes in precipitation and temperature in the

7 future are likely to apply additional pressure to wetland. In this context, a methodology for

8 assessing and comparing the respective impacts of groundwater abstraction and climate

9 change on a groundwater-fed wetland $\left(135 \mathrm{~km}^{2}\right)$ located in Northwest France, is presented. A

10 groundwater model was developed, using flexible boundary conditions to represent surface-

11 subsurface interactions which allowed examination of the extent of the wetland areas. This

12 variable parameter is highly important for land management and is usually not considered in

13 impact studies. The model was coupled with recharge estimation, groundwater abstraction

14 scenarios, and climate change scenarios downscaled from 14 GCMs corresponding to the

15 A1B greenhouse gas (GHG) scenario over the periods 1961-2000 and 2081-2100. Results

16 show that climate change is expected to have an important impact and reduce the surface of

17 wetlands by $5.3 \%$ to $13.6 \%$. In comparison, the impact of groundwater abstraction (100\%

18 increase in the expected scenarios) would lead to a maximum decrease of $3.7 \%$. Results also

19 show that the impacts of climate change and groundwater abstraction could be partially

20 mitigated by decreasing or stopping land drainage in specific parts of the area. Water

21 management will require an appropriate compromise which encompasses ecosystem

22 preservation, economic and public domain activities.

23 Keywords: Peatlands, groundwater, wetlands, humid zone, climate change, groundwater 24 pumping 


\section{Introduction}

Peatlands are complex and fragile ecosystems driven by many physical, chemical, and biological processes. Numerous studies have provided a comprehensive understanding of wetland hydrology, especially regarding the interactions between surrounding aquifers and surface water networks (Bradley, 2002; Frei et al., 2010; Grapes et al., 2006; Lischeid et al., 2010; Reeve et al., 2000; van Roosmalen et al., 2009; Wilsnack et al., 2001; Winter, 1999). Because peat soils can serve as sinks, sources, and transformers of nutrients and other chemical contaminants, they have a significant impact on water quality, ecosystem productivity and greenhouse gas emissions (Hemond and Benoit, 1988; Johnston, 1991; Kasimir-Klemedtsson et al., 1997; Roulet, 2000). The extent of peatlands is tending to decrease worldwide, (Estimated to 6 \% over the period 1993-2007 - Prigent et al. (2012)). However, peatlands are considered as important carbon reserves (15-30 \% according to Botch et al. (1995); Turunen et al. (2002)), and important potential sources of $\mathrm{CO}_{2}$ even though they cover only 3 to $4 \%$ of emerged areas on the earth. As the oxygen concentration in peat increases due to water drawdown, surface decomposition is enhanced by bacterial aerobic processes (Holden et al., 2004). Oxygen enhances organic matter mineralization, leading to $\mathrm{CO}_{2}$ release to the atmosphere and nutrients production, particularly carbon-bound nitrogen and sulphur. Decreasing groundwater levels can also cause land subsidence, due to the reorganization of the peat structure (Silins and Rothwell, 1998).

The hydrology of the peat layer and extent of this peat area are impacted by drainage for agriculture, groundwater abstractions in underlying aquifers and climate change. The general impact of climate change on hydrological systems has been studied, focusing on surface water (Christensen et al., 2004; Fowler et al., 2007a), and more recently on groundwater reserves (e.g. Goderniaux et al., 2009; Goderniaux et al., 2011; Green et al., 2011; Herrera-Pantoja and Hiscock, 2008; Holman et al., 2011; Scibek et al., 2007; Woldeamlak et al., 2007). However, 
few studies have addressed the impact of climate on the evolution of peatlands, which are

51

52 specific ecosystems located at the interface between surface water and groundwater. Moreover, the respective impacts of climate change and anthropic water abstraction on wetlands have not been investigated and compared.

Peatlands are commonly observed in lowland areas where shallow gradients, impermeable substrates or topographic convergence maintain saturation. Peatland classification is generally related to two fundamental factors: source of nutrients and source of water. Bogs or ombrotrophic peatlands are dependent on precipitation for water and nutrient supply, whereas minerotrophic peatlands or fens rely on groundwater (Johnson and Dunham, 1963). As a consequence, two different points of view have generally been adopted in studies of the impact of climate change. Thompson et al. (2009) performed an impact study on the Elmley marshes $\left(8.7 \mathrm{~km}^{2}\right)$ in England using a coupled surface-subsurface model, where subsurface is represented by a single uniform layer. In their study, precipitation and evapotranspiration were the main hydrological processes, due to the impoundment of the marshes within embankments and their low hydraulic conductivity. Conversely, other studies emphasized the importance of the interactions with groundwater. Candela et al. (2009) developed a groundwater model $\left(415 \mathrm{~km}^{2}\right)$ for a basin in the Island of Marjorca (Spain), to assess the impact of climate change on groundwater resources and on springs discharging into a smaller wetland area. Herrera-Pantoja et al. (2012) used a generalized groundwater model of eastern England wetlands to assess climate change impacts on water levels and their consequences on typical plant species. Barron et al. (2012) assessed the risks for wetlands and groundwaterdependent vegetation in the southern half of the Perth Basin $\left(\sim 20000 \mathrm{~km}^{2}\right.$, Australia) under future climate change scenarios. Their study is based on a global approach using coefficients of groundwater sensitivity to climate change, and a regional-scale groundwater model. 
74 In this study, we considered peatlands as components of a complex system where the different 75 surface and subsurface compartments interact. Our general objective was to evaluate and 76 compare the competing impacts of climate change and water abstraction activities on 77 groundwater storage and the extents of wetland areas. We focused on a $135 \mathrm{~km}^{2}$ peatland area 78 in the Cotentin marshes (northwest France). Our three main objectives were: (i) to understand 79 surface-subsurface connectivity and associated wetland hydrological sensitivity, (ii) to 80 quantify the impact of projected increases in groundwater abstraction, and (iii) to estimate the 81 impact of climate change at the end of this century. These objectives have been attained by 82 using a 3D groundwater model for the Cotentin wetland area.

\section{2. Study area}

\section{2.1. The Cotentin marshes}

85 The Cotentin marshes are located within a large watershed in Normandy (Northwest France, 86 see Figure 1). The study area is situated within a natural reserve, and extends over 87 approximately $135 \mathrm{~km}^{2}$. Topography ranges from 0 to $30 \mathrm{~m}$ above sea level. Mean annual precipitation and potential evapotranspiration for the period 1946-2010 (from two climatic stations, Figure 1) were $910 \mathrm{~mm} / \mathrm{yr}$ and $630 \mathrm{~mm} / \mathrm{yr}$, respectively. In the lowland areas, the vast wetlands and peatlands partly consist of peat soils and are located along 3 main rivers:

91 the 'Sèves' in the North, the 'Holerotte' in the West, and the 'Taute' in the South (Figure 1). As 92 suggested by hydrologic fluxes and chemical features (Auterives et al., 2011), this wetland 93 area is closely related to groundwater. It is connected with an underlying highly transmissive 94 aquifer and surface-water bodies are integral parts of the groundwater flow systems. For 95 several centuries, this large wetland has undergone numerous disturbances. In the $18^{\text {th }}$ century 96 the wetland was flooded 9 months per year (Bouillon-Launay, 1992). Since 1712, a human97 controlled drainage system has gradually been set up. From 1950 until now, the flooding 
season has been reduced to only 3 months on average due to agricultural constraints. The top peat profile is thus subjected to longer periods of desiccation. Beside agricultural pressure, the underlying aquifer is also used as a drinking water supply, since 1992. Due to an increasing demand for high-quality water, the authorities plan to increase groundwater abstraction in the near future. The Cotentin peatlands are nevertheless also classified as a natural reserve for specific wildlife and plant species. Additionally, geotechnical perturbations such as the collapse of parts of houses or fissures in constructed walls have also been reported along the border of the peatland. These perturbations have generated public manifestations, and the filing of legal claims in early 2012. It was often claimed during these manifestations that groundwater extraction was responsible for the observed damage. As a consequence, the Cotentin marshes are at the centre of different interests, which must be integrated by stakeholders into their management plans: ecological activities through the preservation of wetlands, economic activities through the preservation of farmland, and public domain activities through the distribution of drinking water.

\subsection{The Sainteny-Marchésieux aquifer}

The geology of the Sainteny-Marchésieux study area, located in the Cotentin marshes, corresponds to a graben structure (Baize, 1998), bounded by NE-SW and NNW-SSE faults (Figure 2), with a depth of $150 \mathrm{~m}$. The substratum is considered as impermeable and corresponds to Precambrian geological formations to the south and west and Permo-Trias to the east and the north (Figure 2). Within the graben structure, two different aquifer areas can be distinguished (Figure 2). (1) The Sainteny aquifer in the northwest extends over approximately $35 \mathrm{~km}^{2}$. It consists of shelly sands up to $100 \mathrm{~m}$ thick, characterized by relatively high hydraulic conductivity. (2) The Marchésieux aquifer, in the south, extends over approximately $100 \mathrm{~km}^{2}$. This area is characterized by different lithologies, including sandstones, shales and sandy loams. These formations have a maximum total thickness of 
$123150 \mathrm{~m}$ and are considered less permeable than the shelly sands of the Sainteny aquifer. These

124 thick formations are overlain by (1) Holocene peats, ranging in thickness from 1 to 10 meters

125 in the wetland area (Figure 1) and (2) by sands (up to $10 \mathrm{~m}$ ) elsewhere. According to the

126 observed groundwater heads and the hydraulic conductivity of these lithologies, the aquifer is

127 considered as confined below the peatlands and unconfined below the sands.

128 Generally, groundwater flows from southwest to northeast and the aquifer is drained by a

129 dense hydrographic network. High and low areas act as recharge and discharge zones,

130 respectively, (as conceptually shown in Figure 3). Currently, groundwater is predominantly

131 abstracted in the Sainteny aquifer, with about 5 million $\mathrm{m}^{3}$ pumped each year in 5 different

132 existing wells (Figure 1). The Marchésieux aquifer exploitation is limited to a single existing

133 well, with a pumping rate of about 0.14 million $\mathrm{m}^{3}$ per year. Groundwater abstraction 134 represents approximately $9 \%$ of the total recharge rate.

135 In the north of the catchment, the peatlands in the 'Baupte' area (Figure 1) were exploited 136 from the 1950s to 2006. Peat extraction implied a considerable lowering of the water table.

137 Currently, a large pit of about $0.4 \mathrm{~km}^{2}$ remains and the average water level in this zone is 138 artificially maintained about $4.9 \mathrm{~m}$ below the ground surface to avoid flooding of certain areas 139 of farmland.

140 3. Modeling

\subsection{Model implementation}

142 The 3D groundwater model has been developed with the Modflow 2005 finite difference code 143 (Harbaugh, 2005). The modeled area corresponds to the Sainteny-Marchésieux 144 hydrogeological catchment which is globally defined by the limits of the graben structure. 145 Boundary conditions along the model limits have been implemented as follows (Figure 2): 
- Sections B-C, D-E and F-A correspond to the interface between bedrock and sediments inside the graben. According to the geology and measured groundwater levels, this interface is considered as impermeable. A no-flow boundary condition is prescribed along these sections.

- Section A-B corresponds to a stream section, which is considered as a main drainage divide. A no-flow boundary condition is implemented along this stream section.

- Sections C-D and E-F also correspond to the graben limits but measured groundwater levels show that groundwater fluxes, from the adjacent geological formation, feed the aquifer. Along these sections, a groundwater flux, equal to the recharge rates times the upstream areas, is prescribed.

157 package') is applied at the ground surface. This boundary condition enables groundwater to

158 leave the system only when the simulated hydraulic head is above the topographic surface, 159 according to a conductance coefficient. This type of boundary condition is particularly useful 160 in this wetlands context, where the extent of the discharge areas is dependent on recharge 161 rates. Fluxes abstracted for drinking water distribution are applied to the nodes corresponding 162 to the pumping wells (see section 3.5.1). Finally, a prescribed head boundary condition is 163 applied to the Baupte peatland extraction area $\left(0.4 \mathrm{~km}^{2}\right)$ where the water level is artificially 164 maintained at $4.9 \mathrm{~m}$ below the ground surface. This boundary condition can be used in this 165 circumstance because the calculated heads are never lower than the bottom of the peat 166 exploitation. The bottom of the model is considered as impermeable, and implemented with a 167 no-flow boundary condition. 
The study area was discretized using 90 by $90 \mathrm{~m}$ cells and 6 layers, with a total number of approximately 100,000 cells. The top of the first layer corresponds to the topographic surface, extracted from a digital elevation model of the region. This first layer is $10 \mathrm{~m}$ thick and

172 corresponds to the quaternary peats and upper sands. The interface between the first and

173 second layer corresponds to the top of the aquifer which is composed of shelly sands, sandstones and sandy loams (see Section 2). The depth of the aquifer base has been defined from borehole data and ranges from $70 \mathrm{~m}$ to $150 \mathrm{~m}$ below sea level. Five horizontal finite difference layers are used to represent this aquifer.

\subsection{System stresses}

Recharge and wells pumping rates are applied as input to the model. Pumping rates are calculated from the abstracted groundwater volumes, which have been collected for years by the regional water agencies. Recharge values are applied on the whole modeled area. They are computed externally using a water balance method, based on a modified version of the parsimonious monthly lumped model GR2M (Mouelhi et al., 2006). The GR2M model obtained one of the best performances in a benchmark test of 410 basins throughout the world in different climatic contexts, as compared to 9 other models with generally more parameters

185 (Mouelhi et al., 2006). The GR2M model has been designed to separate rainfall into actual 186 evapotranspiration, surface runoff and transfer to the routing store, which is interpreted here 187 as aquifer recharge (see model description at http://www.cemagref.fr/webgr/IndexGB.htm). 188 Observed rainfall and potential evapotranspiration, provided by 'Meteo France', are used as 189 GR2M inputs. The GR2M model is calibrated to monthly surface runoff data, which are 190 calculated by baseflow separation from measured river flow rate time series. Data are 191 available over a time frame ranging from January 1999 to December 2000 and January 2003 
192

193

194

195

196

197

198

199

200

201

202

203

204

205

206

207

208

209

210

211

212

213

214

215

to December 2007 and includes both wet (1999-2000) and very dry years (2003-2004), which maximizes the descriptive ability of the model over a large interval of climatic fluctuations. This is particularly important in the context of future climate change where applied stresses typically go beyond the calibration interval. The calibration is limited to a 1-parameter calibration process, which is here the soil storage capacity, and carried out on the square root of surface runoff to allow equal weight to high and low flow situations (Oudin et al., 2006). In the optimization process, the Nash-Sutcliffe criterion (Nash and Sutcliffe, 1970) was used as the objective function, and supplemented with the constraint to conserve the total amount of surface runoff ( $\sum Q_{o b s} / \sum Q_{\text {sim }}=1$ ), where $Q_{\text {sim }}$ and $Q_{o b s}$ are simulated and observed surface runoff (Figure 4). The Nash-Sutcliffe criterion is 0.70 and the calculated annual recharge ranges from $164 \mathrm{~mm} / \mathrm{yr}$ to $338 \mathrm{~mm} / \mathrm{yr}$. On an annual basis, the total amount of water in rivers is also preserved. The sum of simulated surface runoff and recharge is very close to the observed flow rate in rivers. For the wet (1999-2000) and dry (2003-2004) years, the error is equal to 2 and $4 \%$, respectively. Checking this relation prevents under or overestimation of calculated annual recharge due to errors on the actual evapotranspiration term. This calibrated 'GR2M' mass-balance model is subsequently used to externally calculate the recharge to be applied as input to the hydrological Modflow model, for historic and future climatic scenarios (see Section 3.5).

\subsection{Calibration and validation of the hydrological model}

The hydrological Modflow model was calibrated to the observed i) aquifer hydraulic heads, ii) spatial distribution of wetland area and iii) stream base-flow. The calibration was performed in steady state conditions for two humid and dry contrasted years, 1999-2000 ( $\mathrm{R}=338 \mathrm{~mm} / \mathrm{yr})$ and 2003-2004 (R=164 mm/yr), respectively, for which daily climatic data were available. The calibration was performed automatically using the PEST module coupled 
with Modflow, and by adjusting the hydraulic conductivities of the different geological

217 formations within specific ranges provided by field tests (Auterives, 2007; Auterives et al., 218 2011). This calibration was validated using data from the hydrologic year 2006-2007 219 ( $\mathrm{R}=263 \mathrm{~mm} / \mathrm{yr})$, which is close to the 1961-2000 average precipitation and temperature statistics (where $\mathrm{R}=250 \mathrm{~mm} / \mathrm{yr}$ ). Results of the calibration are shown in Table 1, Figure 5 and Figure 6, for hydraulic conductivities, groundwater levels and wetland surface, respectively. Table 1 shows the calibrated hydraulic conductivities of the geological formations represented in the model. The seepage conductance is set to a high value, calculated from a hydraulic conductivity which is significantly higher than the hydraulic conductivity of the geological layers. Figure 5 presents residuals for the groundwater levels, calculated as the difference between the observed and simulated values. Figure 6 shows the observed and simulated wetland areas. The "observed wetland areas" are given by cartographic data (data base from the local conservatory park: "Parc Naturel des marais du Cotentin et du Bessin”) which are representative of the mean climatic conditions of the time period 1961-2000. These wetlands are defined as zones where a groundwater level close to the soil surface is maintained during a

231 large part of the year. The "simulated wetland areas" are calculated from the model outputs. A

232 finite difference cell is considered as part of the wetland area when the simulated groundwater level is less than $0.5 \mathrm{~m}$ below the ground surface. Observed groundwater discharge volumes

234 are calculated as the difference between the main stream inlets (Sèves, Holerotte and Taute) 235 and outlets (Sèves and Taute) volumes, where gauging stations are located (Figure 1). The 236 errors between observed and simulated volumes of groundwater drained from the aquifer to 237 the surface domain (through the seepage boundary condition) are below $5 \%$. The volume of 238 water extracted by the prescribed head boundary condition is equivalent to the quantity of 239 water pumped by the Baupte peatland manager: approximately 10 million $\mathrm{m}^{3}$ each year. 


\subsection{Future scenarios}

241 Future scenarios for groundwater abstraction and climate change were applied as input to the

242 calibrated model, to assess their respective impacts on the catchment, with particular focus on

243 wetland extension. These scenarios are compared with a reference simulation corresponding

244 to the average recharge and groundwater abstraction for the period 1961-2000. The reference

245 recharge is $250 \mathrm{~mm} / \mathrm{yr}$ and the abstracted groundwater volumes are 5 million $\mathrm{m}^{3} / \mathrm{yr}$. The

246 climate change, groundwater abstraction and management scenarios considered in this study

247 are summarized in Table 2.

\subsubsection{Future groundwater abstraction}

Groundwater abstraction volumes that will be required in the future are defined from projections made by the local water agency. Four different scenarios are tested, considering an increase in groundwater demand of $10 \%, 20 \%, 50 \%$ and $100 \%$, relative to the current volumes (5 million $\mathrm{m}^{3} / \mathrm{yr}$ ) (Table 2). Two different management plans are considered and tested with the model. The first plan consists in applying the increase in groundwater demand to the pumping rates of the 6 existing wells currently used (Figure 1) (Scenarios 1 to 4 in

Table 2). The second plan consists in using two new wells located in the Marchésieux aquifer (Figure 1) to support the increase in groundwater demand (Scenarios 5 to 8). In this second

257 plan, the abstraction flow rates in the existing wells are kept constant.

\subsubsection{Climate change}

259 Climate change impact studies cannot directly use the output of global climate models (GCM)

260 because of discrepancies between the extent of the impact model $\left(135 \mathrm{~km}^{2}\right)$ and the horizontal 261 resolution of these numerical models ( $250 \mathrm{~km}$, see Solomon et al. (2007)). Downscaling 262 methodologies are commonly used to overcome this problem. Such methods are either 263 dynamically and/or statistically based. In the current study, DSCLIM, a statistical 
264 downscaling methodology developed at CERFACS was applied to work at an $8 \mathrm{~km}$

265 resolution. This method is based on the physical relationship between large-scale atmospheric

266 circulations and the local-scale climate (Boé et al., 2009; Fowler et al., 2007b; Pagé et al., 267 2009). Although downscaling methods are also a source of uncertainty (Fowler et al., 2007a),

268 we chose to focus on climate model uncertainty, which has been shown to be conservative for 269 hydrological impact studies in the French context (Ducharne et al., 2009). This was applied to 270 produce climate scenarios for specific chosen locations in France. Using this methodology, 14

271 GCMs were downscaled from the 2007 CMIP3 database for the A1B greenhouse gas (GHG)

272 scenario over the periods 1961-2000 and 2081-2100, as shown in Table 3 (see Solomon et al., 273 2007, for details about the GCMs). Scenario A1B is a sub-category of storyline A1. The A1B 274 scenario was selected because of the availability of several A1B downscaled scenarios, which 275 make possible the evaluation of uncertainties.

276 In the framework of this study, precipitation and PET time series for 64 downscaled cells 277 corresponding to the Cotentin region, for the 14 GCMs, and the periods 1961-2000 and 2081278 2100, were extracted. The period 1961-2000 is considered as the reference case (Table 3). For 279 each cell, each climatic model and each period, the mean annual recharge is calculated using 280 the calibrated GR2M module. The mean recharge rate for the modeled area is then calculated 281 as the average of the 64 cell results. Figure 7 shows temperature and precipitation changes for 282 the period 2081-2100. Compared to the reference period, the mean annual temperature is 283 expected to increase by between 1.3 and $3.7^{\circ} \mathrm{C}$, and annual precipitation is expected to 284 decrease by between 1.8 and $21.3 \%$. The calculated recharge for the reference case is $285250 \mathrm{~mm} / \mathrm{yr}$. All climatic projections induce a decrease in recharge rate ranging from $22 \%$ to $28661 \%$, with an average of $40 \%$ (Table 3). Scenarios 'csri_mk3_0' and 'ipsl_cm4' give the 287 minimum and maximum decreases in recharge, respectively. 


\subsubsection{Coupling climate change, groundwater abstraction and management}

289

290

291

292

293

294

In this impact study, the 3 most contrasted climatic projections, from the 14 downscaled GCMs, are used as input for the hydrological model to investigate the variability between the climate change models (Table 3):

- $\quad$ the most favorable ('csri_mk3_0', termed scenario A, R=194 mm/year)

- $\quad$ the most unfavorable ('ipsl_cm4', termed scenario N, R=97 mm/year)

- $\quad$ the average scenario ('miroc3_2_medres', termed scenario H, R=148 mm/year).

Each climate scenario is coupled with 4 groundwater extraction scenarios (increase of 10, 20, 50 and $100 \%$ ), according to the actual trend in water demand and consumption. Each of these combinations is applied to the two abstraction-management schemes described above: pumping increase in Sainteny (scenarios 12 to 23) or Marchésieux (scenarios 24 to 35) subcatchments.

One of the main objectives was to provide insights into wetland management solutions to mitigate climate change and anthropic impacts. Exploitation of the Baupte peatland (Figure 1) stopped in 2006 but pumping is maintained to avoid flooding the surrounding fields which are used for agriculture. An efficient management of Baupte might therefore provide a solution to reduce negative anthropogenic impacts i.e. water drawdown. The feasibility of this management scheme was studied by complementing the previous scenarios with additional scenarios where pumping is stopped in the Baupte peat exploitation. This stop is simulated in the model by removing the prescribed head boundary condition over the $0.4 \mathrm{~km}^{2}$ 'Baupte' area. As in the previous cases, the simulation was applied to the two abstraction-management schemes i.e. increased pumping in the Sainteny (scenarios 39 to 50) or Marchésieux (scenarios 51 to 62 ) sub-catchments. Three additional scenarios were tested to estimate the respective impacts of past climate change (increase of $1^{\circ} \mathrm{C}$ between 1950 and 2012) and past 
312 anthropogenic activities (Pumping of Baupte and groundwater abstraction) in relation to the

313 current situation.

\section{4. Results}

315 The wetlands compartment corresponds to a natural aquifer outflow and, as shown in the next

316 section, any change in the aquifer recharge or groundwater abstraction is likely to affect

317 wetland area. Future scenarios for groundwater abstraction, climate change and management

318 were then applied as model input. All results for future scenarios were compared to the 319 reference model (1961-2000) with particular focus on the wetland surface area and on water

320 level changes. A summary of these results is presented in Figure 8 and Figure 9. Proportions

321 of the different water balance terms for some scenarios are given in Table 4.

\subsection{Wetland surface reduction}

323

Figure 8 shows the proportion of wetland surface area for the reference model (1961-2000),

324 for future groundwater abstraction scenarios, climate change scenarios (2081-2100) and

325 coupled scenarios. For the reference model, the proportion of wetland area is equal to $24.4 \%$

326 of the total area. This proportion clearly decreases with increasing groundwater abstraction. If

327 these new groundwater volumes are pumped in existing wells, the wetland area decrease

328 ranges from $-0.02 \%$ to $-3.7 \%\left(0.03 \mathrm{~km}^{2}\right.$ and $\left.5.05 \mathrm{~km}^{2}\right)$, according to the magnitude of

329 groundwater abstraction. Conversely, if additional pumping is carried out in new wells in the

330 Marchésieux sub-basin, the impact on wetland area is less important and ranges from $-0.04 \%$

331 to $-1.56 \%\left(0.05 \mathrm{~km}^{2}\right.$ and $\left.2.1 \mathrm{~km}^{2}\right)$. It is partly due to the better distribution of abstracted

332 volumes over the whole area but also because of the groundwater fluxes entering through the 333 southwest catchment limits which feed the aquifer.

334 Simulations of the impacts of climate change indicate a significant reduction of wetland 335 surface area by the end of the century (2081-2100), which is correlated to the decrease of 
336

337

338

339

340

341

342

343

344

345

346

347

348

349

350

351

352

353

354

355

356

357

358

359

360

recharge (ranging from $-22 \%$ to $-61 \%$, see Table 3). Considering unchanged groundwater abstraction, reduction of the wetland surface area ranges from $-13.64 \%\left(18.4 \mathrm{~km}^{2}\right)$ for the worst climatic scenario $\mathrm{N}$ (recharge of $97 \mathrm{~mm})$ to $-5.34 \%\left(7.2 \mathrm{~km}^{2}\right)$ for the most favorable scenario A (recharge of $194 \mathrm{~mm}$ ). These results also provide important information about the respective influence of groundwater abstraction and future climate change. On the scale of the modeled area as a whole, climate change generally induces a larger reduction in wetland area, than any of the groundwater abstraction scenarios. Although scenario $\mathrm{A}$ is the most "favorable” climatic scenario, the impact on wetland surface area is actually more important than the worst groundwater abstraction scenario. As shown in Figure 8, the combined impact of climate change and groundwater abstraction is even more important and ranges from $5.36 \%$ to $-16.04 \%$, depending on the climate change scenario and location of the pumping wells.

Regarding water balance terms, fluxes entering the domain correspond to the recharge applied on the top cells and groundwater entering by specified flux boundary condition (See Section 3.1). These specified groundwater fluxes represent $36 \%$ of total water influx in the modeled domain. Fluxes leaving the domain correspond to the groundwater discharge, pumpings in the public water distribution wells and pumpings in the Baupte peat exploitation. For the reference scenario, these terms correspond to $72 \%, 9 \%$ and $19 \%$ of total influx, respectively. Numerical simulations allow quantifying the absolute and relative evolution of these terms considering various stresses (Table 4). For climate change scenarios with unchanged groundwater abstraction, absolute values of all terms logically decrease with recharge and more extreme climate change. However, the proportion of abstracted groundwater (public wells and Baupte) relatively to total influx increases to the detriment of groundwater discharge. For the worst climate change scenario (scenario N), groundwater discharge is only $32.1 \%$ of total influx. In cubic meters, this represents a decrease of more 
361

362

363

364

365

366

367

368

369

370

371

372

373

374

375

376

377

378

379

380

381

382

383

than $80 \%$ compared to the reference simulation. Finally, Table 4 also shows that the decrease of total water influx in climate change scenarios is greater than groundwater abstraction by public wells, which partly explains the preponderant impact of climate change on wetland areas. Relations between input stresses and hydrogeology variables are however complex and dependent on many parameters (such as geology, topography, locations of pumping wells), so that numerical modeling is required for an objective impact quantification.

\subsection{Wetland spatial distribution}

Previous analyses provide overall information on the scale of the modeled area. However, the different scenarios also imply different impacts in terms of the distribution of drawdown within the wetlands (Figure 9).

Increasing pumping rates by $50 \%$ in existing wells induces a water level decrease of between $25 \mathrm{~cm}$ and $40 \mathrm{~cm}$ in the Sainteny Northern wetland, while water levels are not significantly affected in the Marchésieux Southern wetland (Figure 9A, Scenario Pumping $+50 \%$ with existing wells, Scenario 3). Conversely, increased pumping in new wells located in the Marchésieux basin leads to a better distribution of the impacts (Figure 9B, Scenario Pumping $+50 \%$ with existing and 2 new wells, Scenario 7). The impact of climate scenarios is greater but better distributed over the whole area (Figure 9C, Scenario A and Figure 9D, Scenario N). For climate change scenario A, water levels in the Northern wetland are lowered by about 50 to $60 \mathrm{~cm}$. In the Southern area, the water levels decrease by 25 to $40 \mathrm{~cm}$ in the east and by 80 to $90 \mathrm{~cm}$ in the most elevated part of the modeled area. Generally, wetland areas are more impacted in the Northern catchment, where groundwater levels are also affected by the Baupte peat exploitation. In this catchment, all flooded areas disappear with the worst climate change scenario (scenario $\mathrm{N}$ ). 
384 These results show the possible evolution of the wetland area according to different 385 groundwater abstraction options and climate change scenarios for the end of the century 386 (2081-2100). The wetland area is expected to decrease in any case, and the impact of climate 387 change is stronger than the impact of groundwater abstraction.

\subsection{Effect of pumping in the Baupte peat exploitation}

389

390

391

392

393

394

395

396

397

398

399

400

401

402 403 404 405 406

One potential solution to save water and mitigate climate and pumping impacts would be to reduce pumping in the Baupte peat exploitation (Figure 8). For all scenarios, stopping all pumping in Baupte would allow a wetland recovery of $4.45 \%$ to $9.19 \%$ of the total area depending on the groundwater abstraction and climate change scenario. Considering the most favorable climate change scenario (Scenario A), the wetland surface area would be approximately equivalent to the current situation, whatever the pumping scenario used (see Figure 8). This effect is apparent in Figure 9E, Scenario 36, where water levels increase by 75 to $25 \mathrm{~cm}$ in the Sainteny area. For the other scenarios, stopping all pumping in Baupte is not enough to completely balance the loss of wetlands due to climate change. Considering the worst scenario (climate scenario $\mathrm{N}$ and Pumping $+100 \%$ with existing wells), reduction of the wetlands area would still attain 9.67\%, even if pumping in Baupte is stopped (Figure 9F).

\section{Discussion}

\subsection{Uncertainty and model limitations}

Using numerical models induces some uncertainty that affect the subsequent simulations. This uncertainty may be generated from various possible sources (Refsgaard et al., 2006). Some of them are discussed here below. By adopting a multi-model approach for the climate scenarios, it is possible to incorporate the uncertainty related to the climate models and the uncertainty derived from climate model selection into the assessment of climate change impacts on the 
407 Sainteny-Marchésieux catchment. All the 14 climate change scenarios predict a decrease in 408 recharge ranging from 22 to $61 \%$ (Table 3). It results in a decrease of water level and total 409 wetland surface area ranging from 5.3 to $13.6 \%$ (Figure 8), meaning that this decrease is 410 highly probable from this point of view.

411 The accuracy of the predictions will also depends on the quality of the calibration, which 412 varies according to the different variables considered in the study. The volume of drained 413 water presents the major uncertainty because only partial observed stream-discharge data are 414 available. In spite of the lack of data, the 3D hydrogeological model satisfactorily reproduces 415 the measured volumes of drained water with a good correlation $\left(\mathrm{R}^{2}=0.9\right)$ between simulated 416 and observed values (error less than $5 \%$ ). Similarly, the volumes leaving the system by the 417 Baupte boundary condition match the measured quantity of water currently pumped from the 418 peat exploitation. Concerning the hydraulic heads (Figure 5), all residuals are lower than 1m, except for two wells. The model is able to simulate groundwater levels according to different annual climate conditions, even though it slightly over-estimates the hydraulic heads in wet periods and under-estimates them in dry periods, which could also imply that the predicted 422 impacts are slightly overestimated.

423 We here emphasize the relative simplicity of the model, which is focused on the evolution of 424 wetlands extension. Particularly, the use of a seepage boundary condition for the whole modeled surface enables some flexibility regarding the distribution of discharge zones over 426 the domain. These discharge zones are actually variable according to climatic conditions. As 427 an example, low recharge rates induce lower water table and disconnection of river sections, 428 which also implies a decrease of groundwater discharging zones and wetlands areas 429 (Goderniaux et al., 2013). Conceptualizing and representing these processes in the numerical 430 model is crucial to quantify the extents of these wetland areas as a function of recharge. 431 Specifying the locations of rivers and using river boundary conditions appears too restrictive 
432 in this case. Although simple, the approach adopted however provides a rapid and easy 433 characterization of wetland extension, which is clear and important parameter for 434 stakeholders.

435 More complex approaches are available for modeling hydrological systems. Integrating more 436 processes into the same model has the advantage of providing more realistic simulations. 437 Indeed it is very useful to have realistic water budget terms. That's why, particularly, fully 438 integrated surface-subsurface models are more and more used (Ebel et al., 2009; Jones et al., 439 2008; Liggett et al., 2013). However, using more complex hydrological models also involves 440 a large number of parameters, requires important computing times, and makes the calibration 441 step more difficult, so that significant uncertainty may remain from this source. There is a 442 lively debate on the question of the models complexity to be used (Hill, 2006; Hunt and 443 Zheng, 1999). In this study, the model used includes simplifications, which presents some 444 advantages but also some limitations. The processes related to the water transfers in the 445 partially saturated zone are for example not simulated by the hydrological model. The role of 446 these transfers is limited regarding the results of this study because simulations are performed 447 in steady state and the partially saturated zone remains relatively thin. However, for transient 448 simulations, and particularly to evaluate seasonal fluctuations, water transfers in this zone 449 should be further studied. Similarly, the verification of the water budget terms for the GR2M 450 recharge model and the Modflow hydrological model is currently based on annual data. A 451 finer time-discretization would be required to account for seasonality effects. Moreover, more 452 observed data about wetlands extents at the seasonal timescale would also be required. While 453 this study has shown the long term effect of climate change on wetland areas, the implications 454 regarding these seasonal fluctuations remain to be studied and constitute a perspective of this 455 work. 


\subsection{Groundwater abstraction and climate change scenarios}

457 The groundwater abstraction scenarios were implemented to evaluate the sensitivity of the

458 Cotentin wetlands to future increasing demand. The pumping simulations reflect realistic 459 scenarios of future exploitation, according to local water agencies. In general, pumping in the 460 main aquifer decreases upward fluxes (from the aquifer to the peat) and increases downward

461 fluxes (from the peat to the aquifer). These modifications of water transfer from one 462 compartment to the other may affect water and peat chemistry. Enhanced downward fluxes 463 will actually bring different water, with higher oxygen content and different composition, to 464 the deeper peat layers which may, in turn, affect peat structure, mineralization processes, and water quality. Pumping scenarios which include new extraction wells in the Marchésieux subcatchment should therefore be preferred to limit environmental impact (see Figure 8 and Figure 9). Although this hydrological basin is less permeable, a similar water volume abstracted (relative to the amount currently extracted at Sainteny) results in a smaller reduction of the wetland water level (Figure 8). Moreover, future increased exploitation should remain below a threshold of 10 to $20 \%$ of the current extracted volume to limit the potential impact on wetland surface area.

472 The 14 climate change scenarios predict a decrease in recharge ranging from 22 to $61 \%$

473 (Table 3) which results in a decrease of total wetland surface area of 5.3 to $13.6 \%$ (Figure 8).

474 In the long term, the model results clearly show and quantify that the water stresses and the 475 impact on the wetland extents are much greater for the climate change scenarios than for the 476 groundwater abstraction scenarios.

477 Therefore, climate change constitutes a major driver as compared to groundwater exploitation 478 in the modeled area. However, the effects of climate change will be gradually visible over 479 several decades, whereas the other effects are already severe. Furthermore, as all 480 anthropogenic effects are cumulative, the expected impacts of climate change should 
481

482

483

484

485

486

487

488

489

490

491

492

493

494

495

496

497

498

499

500

501

502

503

504

505

emphasize the urgent need for mitigation plans. In this context, the modeling results also highlight the effect of the Baupte exploitation on peat water levels. Peat extraction was stopped in 2006. However, local authorities decided to maintain water pumping in order to avoid flooding agricultural fields. In the near future, pumping could be decreased in order to mitigate the impacts of climate change in the Northern Sainteny catchment.

Thompson et al. (2009) found similar conclusions regarding climate change impact on a wetland area located in south-eastern England, with significant wetland area decrease by the 2050s. The comparison is however difficult as the influence of the groundwater compartment seems less preponderant in their study area. Other studies do not directly calculate wetland extents, but concentrate on groundwater levels and discharge rates evolution. Candela et al. (2009) project decreases in spring discharges to a wetland in Majorca (Spain), for 2025 and 2 emission scenarios (A2 and B2). They calculate that a reduction or alternative management of the groundwater abstraction is needed to avoid the partial or complete disappearance of the wetland. Finally, Herrera-Pantoja et al. (2012) calculated significant declining trends in groundwater levels in a wetland located in Eastern England, by the end of the century and using a ‘high' greenhouse gases emissions.

\subsection{Anthropogenic influences prior to 2012}

During the last years, it was often claimed that groundwater extraction was responsible for peatland desiccation and geotechnical damages. To provide a scientific basis to this controversy, the model has been used to analyse the respective effects of anthropogenic activities on groundwater levels over the period 1950-2012. The effects of both the Baupte peatland exploitation and groundwater abstraction were analysed by removing both pumping from the current situation. The effect of climate change was considered by assuming an increase in annual temperature of $1^{\circ} \mathrm{C}$ from 1950 to 2012, as observed on several climatic stations in the region. The recharge and hydrological models were run with a temperature one 
506 degree lower than the current temperature. The results indicated a general decrease in water

507 level, in the investigated zone, between 1950 and 2012. Baupte exploitation and groundwater

508 abstraction had relatively similar impacts ranging from 50 to $85 \mathrm{~cm}$ and 35 to $70 \mathrm{~cm}$,

509 respectively. Climate change had a more limited impact of about $20 \mathrm{~cm}$ over the last 60 years.

510 The model developed in this study provides interesting insights in the quest to find solutions

511 for this territorial management crisis. It enables the respective impacts of all human activities

512 for the last 60 years to be quantified. The decrease in water-level was reported by local

513 inhabitants, but its extent and the period of occurrence remained unclear. Although the effect

514 of drainage which occurred from the $17^{\text {th }}$ century onwards and more intensively after the

515 Second World War, could not be taken into account, the model results show that more recent

516 human-induced changes have in any case had a major effect during the last decades

517 independently of previous management schemes. Clearly, none of the three anthropogenic

518 effects considered (Baupte exploitation, groundwater exploitation, and climate change) can

519 alone be considered as responsible for peat desiccation. The current state of the peatland

520 appears to result from increasing stress which has several causes. The model results were

521 particularly unexpected for the end-users, who had mainly focused on the impact of

522 groundwater exploitation and had never integrated the potential influence of climate change.

523 This result is particularly important with regard to previous studies which had already

524 indicated severe drawdown (Auterives et al., 2011) and chemical oxidation of the peat

525 (Bougon et al., 2011; De Ridder et al., 2012).

526 6. Conclusion

527 The water fluxes occurring between large wetlands and underlying aquifers were analysed by

528 modeling. A simple model was used to simulate groundwater levels, river fluxes through the

529 wetlands and wetland surface extension. The surface flooded is an important parameter for 
530

531

532

533

534

535

536

537

538

539

540

541

542

543

544

545

546

547

548

549

550

551

552

553

wetland management and special emphasis was given to this variable. It was computed by applying the seepage boundary condition to the entire area modeled, and measuring the water level in the wetland aquifer.

The model was used to analyse three different anthropogenic effects: (1) groundwater exploitation in the underlying aquifer, (2) wetland water abstraction in a peat exploitation quarry, and (3) the impact of climate change using data from 14 downscaled climate models.

A $100 \%$ increase in the groundwater abstraction rate had a maximum impact of $3.7 \%$ on the current wetland surface. Climate change is expected to have a greater impact with potential reduction of the wetland surface area ranging from 5.34 to $13.64 \%$. Although peat exploitation has ceased, water pumping has been maintained to avoid flooding farmland. The model indicates that the climate change effects could be partly compensated by decreasing and then stopping this pumping.

Finally, in order to understand the origin of the geotechnical damage observed in recent years, the model was used to investigate the respective impacts of different anthropogenic activities prior to 2012. Results revealed that during the last 60 years, a wetland water-level decrease of 40 to $90 \mathrm{~cm}$ could be attributed to the combined impacts of groundwater and peatland water exploitation. It is clearly apparent that all these human activities contribute to lower the peat groundwater level and have already severely destabilized peat functioning. All these activities have to be taken into account in future management strategies which it is urgent to define. Water management will require an appropriate compromise which encompasses ecosystem preservation, economic and public domain activities.

\section{Acknowledgements}

This work was carried out within the framework of a project funded by the Water Agency (Agence de l'eau Seine Normandie) and the Regional structures (Conseil Régional de 
554 Normandie et Conseil Général de la Manche) and supported by the Parc des Marais du

555 Cotentin et du Bessin. It was also part of the project CLIMAWAT (Adapting to the Impacts

556 of Climate Change on Groundwater Quantity and Quality), EU-RDF INTERREG IVA France

557 (Channel)-Englandprogram. 
559

560

561

562

563

564

565

566

567

568

569

570

571

572

573

574

575

576

577

578

579

580

581

582

583

584

585

586

587

588

589

590

591

592

593

Auterives, C., 2007. Hydrological and hydrochemical setting of a peatland connected to a regional aquifer: Contentin's peatlands in Normandy, NW-France (In French).

Auterives, C., Aquilina, L., Bour, O., Davranche, M., Paquereau, V., 2011. Contribution of climatic and anthropogenic effects to the hydric deficit of peatlands. Hydrol. Process., 25.

Baize, S., 1998. Tectonique, eustatisme et climat dans un sytème géomorphologique cotier. Le Nord-Ouest de la France au Plio-Pléistocène: exemple du Cotentin.

Barron, O. et al., 2012. Climate change effects on water-dependent ecosystems in southwestern Australia. Journal of Hydrology, 434-435: 95-109.

Boé, J., Terray, L., Martin, E., Habets, F., 2009. Projected changes in components of the hydrological cycle in French river basins during the 21st century. Water Resources Research, 45(8): W08426-W08426.

Botch, M.S., Kobak, K.I., Vinson, T.S., Kolchugina, T.P., 1995. Carbon pools and accumulation in peatlands of the former Soviet Union. Global Biogeochemical Cycles, 9(1): 37-37.

Bougon, N., Auterives, C., Aquilina, L., 2011. Nitrate and sulphate dynamics in peat subjected to different hydrological conditions: Batch experiments and field comparison. Journal of Hydrology(411): 12-24.

Bouillon-Launay, E., 1992. Intérêt des indicateurs hydropédologiques dans la gestion raisonnée des zones humides. PhD Thesis, Université de Caen.

Bradley, C., 2002. Simulation of the annual water table dynamics of a floodplain wetland, Narborough Bog, UK. Journal of Hydrology, 261: 150-172.

Candela, L., von Igel, W., Javier Elorza, F., Aronica, G., 2009. Impact assessment of combined climate and management scenarios on groundwater resources and associated wetland (Majorca, Spain). Journal of Hydrology, 376(3-4): 510-527.

Christensen, N.S., Wood, A.W., Voisin, N., 2004. The effects of climate change on the hydrology and water resources of the Colorado River basin. Climatic Change, 62(1-3): 337-363.

De Ridder, J., Aquilina, L., Francez, A.J., Davranche, M., Nunes, F., 2012. Sulphate release under draining-rewetting constraints in peat. Submitted manuscript.

Ducharne, A., Habets, F., Déqué, M., Evaux, L., 2009. Projet RExHySS: Impact du changement climatique sur les Ressources en eau et les Extrêmes Hydrologiques dans les bassins de la Seine et la Somme.

Ebel, B.A., Mirus, B.B., Heppner, C.S., VanderKwaak, J.E., Loague, K., 2009. Firstorder exchange coefficient coupling for simulating surface water-groundwater 
600

601

602

603

604

605

606

607

608

609

610

611

612

613

614

615

616

617

618

619

620

621

622

623

624

625

626

627

628

629

interactions: parameter sensitivity and consistency with a physics-based approach. Hydrol. Process., 23(13): 1949-1959.

Fowler, H.J., Blenkinsop, S., Tebaldi, C., 2007a. Linking climate change modelling to impacts studies : recent advances in downscaling techniques for hydrological. 1578(September): 1547-1578.

Fowler, H.J., Blenkinsop, S., Tebaldi, C., 2007b. Linking climate change modelling to impacts studies: recent advances in downscaling techniques for hydrological modelling. International Journal of Climatology, 27(12): 1547-1578.

Frei, S., Lischeid, G., Fleckenstein, J.H., 2010. Effects of micro-topography on surfacesubsurface exchange and runoff generation in a virtual riparian wetland - $A$ modeling study. Advances in water resources, 33(11, SI): 1388-1401.

Goderniaux, P. et al., 2009. Large scale surface-subsurface hydrological model to assess climate change impacts on groundwater reserves. Journal of Hydrology, 373(12): 122-138.

Goderniaux, P. et al., 2011. Modeling climate change impacts on groundwater resources using transient stochastic climatic scenarios. Water Resources Research, 47(12): W12516-W12516.

Goderniaux, P., Davy, P., Bresciani, E., De Dreuzy, J.R., Le Borgne, T., 2013. Partitioning a regional groundwater flow system into shallow local and deep regional flow compartments. Water Resources Research, 49(4): 2274-2286.

Grapes, T.R., Bradley, C., Petts, G.E., 2006. Hydrodynamics of floodplain wetlands in a chalk catchment: The River Lambourn, UK. Journal of Hydrology, 320(3-4): 324-341.

Green, T.R. et al., 2011. Beneath the surface of global change: Impacts of climate change on groundwater. Journal of Hydrology, 405(3-4): 532-560.

Harbaugh, A.W., 2005. MODFLOW-2005: The US Geological Survey Modular Groundwater Model--the Ground-water Flow Process.

Hemond, H.F., Benoit, J., 1988. Cumulative impacts on water quality functions of wetlands. Environmental Management, 12(5): 639-653.

Herrera-Pantoja, M., Hiscock, K.M., 2008. The effects of climate change on potential groundwater recharge in Great Britain. Hydrol. Process., 22(1): 73-86.

Herrera-Pantoja, M., Hiscock, K.M., Boar, R.R., 2012. The potential impact of climate change on groundwater-fed wetlands in eastern england. Ecohydrology, 5(4): 401-413.

Hill, M.C., 2006. The practical use of simplicity in developing ground water models. GroundWater, 44(6): 775-810. 
630

631

632

633

634

635

636

637

638

639

640

641

642

643

644

645

646

647

648

649

650

651

652

653

654

655

656

657

658

659

660

661

662

663

664

665

666

667

Holden, J., Chapman, P.J., Labadz, J.C., 2004. Artificial drainage of peatlands: hydrological and hydrochemical process and wetland restoration. Progress in Physical Geography, 28: 95-123.

Holman, I.P., Allen, D.M., Cuthbert, M.O., Goderniaux, P., 2011. Towards best practice for assessing the impacts of climate change on groundwater. Hydrogeology Journal, 20(1): 1-4.

Hunt, R.J., Zheng, C., 1999. Debating Complexity in Modeling. Eos, Transactions American Geophysical Union, 80(3): 29.

Johnson, G.A.L., Dunham, K.C., 1963. The geology of Moorhouse: a national nature reserve in north-east Westmoorland, London: HMSO. .

Johnston, C.A., 1991. Sediment and nutrient retention by freshwater wetlands: Effects on surface water quality. Critical Reviews in Environmental Control, 21(5-6): 491-565.

Jones, J.P., Sudicky, E.A., McLaren, R.G., 2008. Application of a fully-integrated surface-subsurface flow model at the watershed-scale: A case study. Water Resources Research, 44(3).

Kasimir-Klemedtsson, Å. et al., 1997. Greenhouse gas emissions from farmed organic soils: a review. Soil Use and Management, 13(s4): 245-250.

Liggett, J.E., Knowling, M.J., Werner, A.D., Simmons, C.T., 2013. On the implementation of the surface conductance approach using a block-centred surface-subsurface hydrology model. Journal of Hydrology, 496: 1-8.

Lischeid, G. et al., 2010. Assessing coupling between lakes and layered aquifers in a complex Pleistocene landscape based on water level dynamics. Advances in Water Resources, 33(11, SI): 1331-1339.

Mouelhi, S., Michel, C., Perrin, C., Andréassian, V., 2006. Stepwise development of a two-parameter monthly water balance model. Journal of Hydrology, 318(1-4): 200-214.

Nash, J.E., Sutcliffe, J.V., 1970. River flow forecasting through conceptual models part I - A discussion of principles. Journal of Hydrology, 10(3): 282-290.

Oudin, L., Andréassian, V., Mathevet, T., Perrin, C., Michel, C., 2006. Dynamic averaging of rainfall-runoff model simulations from complementary model parameterizations. Water Resources Research, 42(7): W07410-W07410.

Pagé, C., Terray, L., Boé, J., 2009. dsclim: A software package to downscale climate scenarios at regional scale using a weather-typing based statistical methodology.

Prigent, C. et al., 2012. Changes in land surface water dynamics since the 1990s and relation to population pressure. Geophysical Research Letters, 39(8): 2-6.

Reeve, a.S., Siegel, D.I., Glaser, P.H., 2000. Simulating vertical flow in large peatlands. Journal of Hydrology, 227(1-4): 207-217. 
668

669

670

671

672

673

674

675

676

677

678

679

680

681

682

683

684

685

686

687

688

689

690

691

692

693

694

695

696

697

698

699

700
Refsgaard, J.C., van der Sluijs, J.P., Brown, J., van der Keur, P., 2006. A framework for dealing with uncertainty due to model structure error. Advances in water resources, 29(11): 1586-1597.

Roulet, N.T., 2000. Peatlands, carbon storage, greenhouse gases, and the Kyoto Protocol: Prospects and significance for Canada. Wetlands, 20(4): 605-615.

Scibek, J., Allen, D.M., Cannon, A.J., Whitfield, P.H., 2007. Groundwater-surface water interaction under scenarios of climate change using a high-resolution transient groundwater model. Journal of Hydrology, 333(2-4): 165-181.

Silins, U., Rothwell, R.L., 1998. Forest Peatland Drainage and Subsidence Affect Soil Water Retention and Transport Properties in an Alberta Peatland. Soil Science Society of America Journal, 62(4): 1048-1056.

Solomon, S. et al., 2007. Climate Change 2007 - The Physical Science Basis: Working Group I Contribution to the Fourth Assessment Report of the IPCC, Cambridge, UK and New York, NY, USA.

Thompson, J.R., Gavin, H., Refsgaard, A., Sorenson, H.R., Gowing, D.J., 2009. Modelling the hydrological impacts of climate change on UK lowland wet grassland. Wetlands Ecology and Management, 17(5): 503-523.

Turunen, J., Tomppo, E., Tolonen, K., Reinikainen, A., 2002. Estimating carbon accumulation rates of undrained mires in Finland - application to boreal and subarctic regions. The Holocene, 12(1): 69-80.

van Roosmalen, L., Sonnenborg, T.O., Jensen, K.H., 2009. Impact of climate and land use change on the hydrology of a large-scale agricultural catchment. Water Resources Research, 45: W00A15-W00A15.

Wilsnack, M.M., Welter, D.E., Montoya, A.M., Restrepo, J.I., Obeysekera, J., 2001. Simulating flow in regional wetlands with the modflow wetlands package. Journal of the Armerican Water Resources Association, 37(3): 655-674.

Winter, T.C., 1999. Relation of streams, lakes, and wetlands to groundwater flow systems. Hydrogeology Journal(September 1998): 28-45.

Woldeamlak, S.T., Batelaan, O., De Smedt, F., 2007. Effects of climate change on the groundwater system in the Grote-Nete catchment, Belgium. Hydrogeology Journal, 15(5): 891-901. 
Tables

702

703

704

705

706

707

708

709

710

711

712

713

714

715

716

717

718

719

720

721

722

723

724

725

Table 1. Calibrated horizontal and vertical hydraulic conductivities

Table 2. Summary of climate change, groundwater abstraction and management scenarios considered in this study. Scenarios are numbered from 1 to 62 . The 'Ref' scenario corresponds to no climate change and no groundwater abstraction increase. The letters ' $A$ ', ' $H$ and ' $N$ ' for the time slice 2081-2100 correspond to 3 specific GCMs described in Table 3

Table 3. GCMs used for climate projections, related recharge and percentage of decrease relative to current recharge. Climate scenarios $\mathrm{A}, \mathrm{H}$ and $\mathrm{N}$ correspond to the mean and extreme scenarios regarding recharge results.

Table 4. Main water balance terms for the reference and climate change scenarios

\section{Figures}

Figure 1. Location of the Sainteny-Marchésieux basin. A. Map of France. B. Map of the Cotentin region. C. View of the modeled area

Figure 2. Geology of the Sainteny-Marchésieux basin and boundary conditions of the model. A. Geologic cross section. B. Map of boundary conditions of the model

Figure 3. Conceptual model

Figure 4. Monthly surface runoff observed and simulated by the modified version of GR2M model.

Figure 5. Residuals for groundwater levels

Figure 6. A. Observed mean wetlands area. B. Simulated water table depth over the catchment and related limits of the wetlands area (hydrologic year 2006-2007)

Figure 7. Monthly and annual mean temperature and precipitation changes for the 14 climatic models in the Cotentin area. Calendar months are numbered from January to December.

Figure 8. Percentage of calculated wetlands area in the modeled zone, according to scenarios of groundwater abstraction, climate change and management.

Figure 9. Maps of drawdown for different climate change and management scenarios 

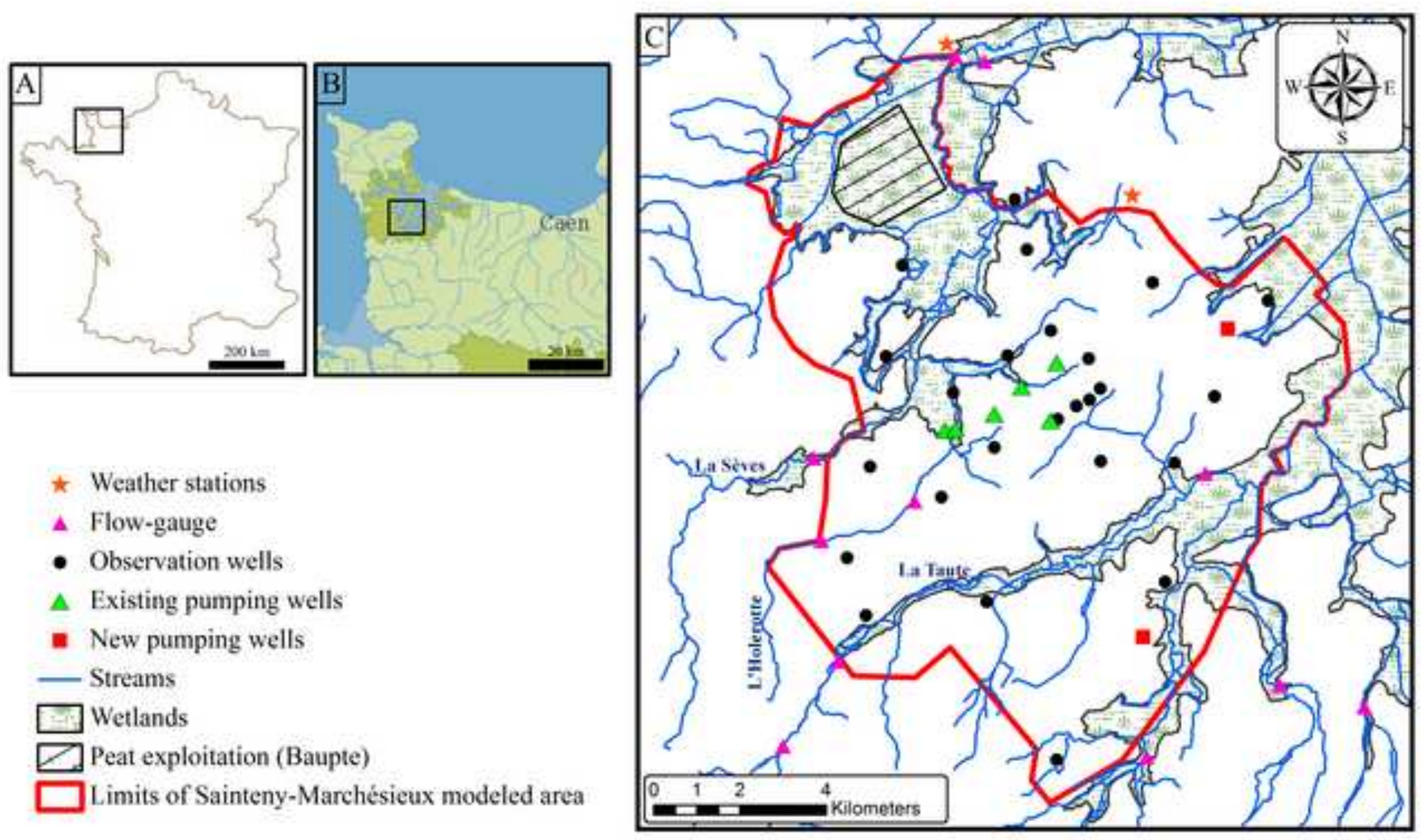

* Weather stations

A Flow-gauge

- Observation wells

$\Delta$ Existing pumping wells

- New pumping wells

- Streams

$\square$ Wetlands

$Z$ Peat exploitation (Baupte)

$\square$ Limits of Sainteny-Marchésieux modeled area 

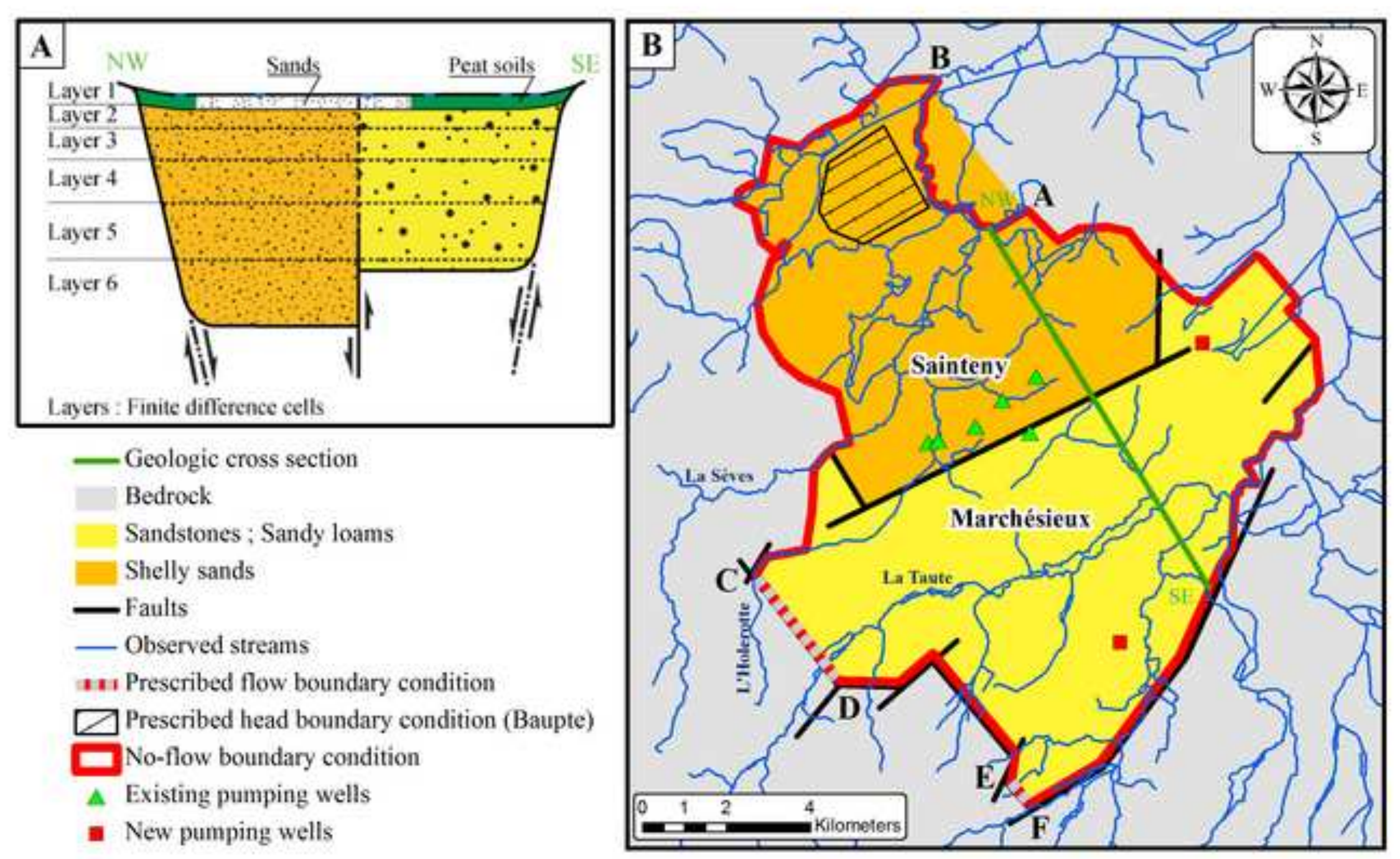

A Existing pumping wells

- New pumping wells

Geologic cross section

Bedrock

Sandstones ; Sandy loams

Shelly sands

- Faults

_ Observed streams

a Prescribed flow boundary condition

$\square$ Prescribed head boundary condition (Baupte)

No-flow boundary condition

Cow 

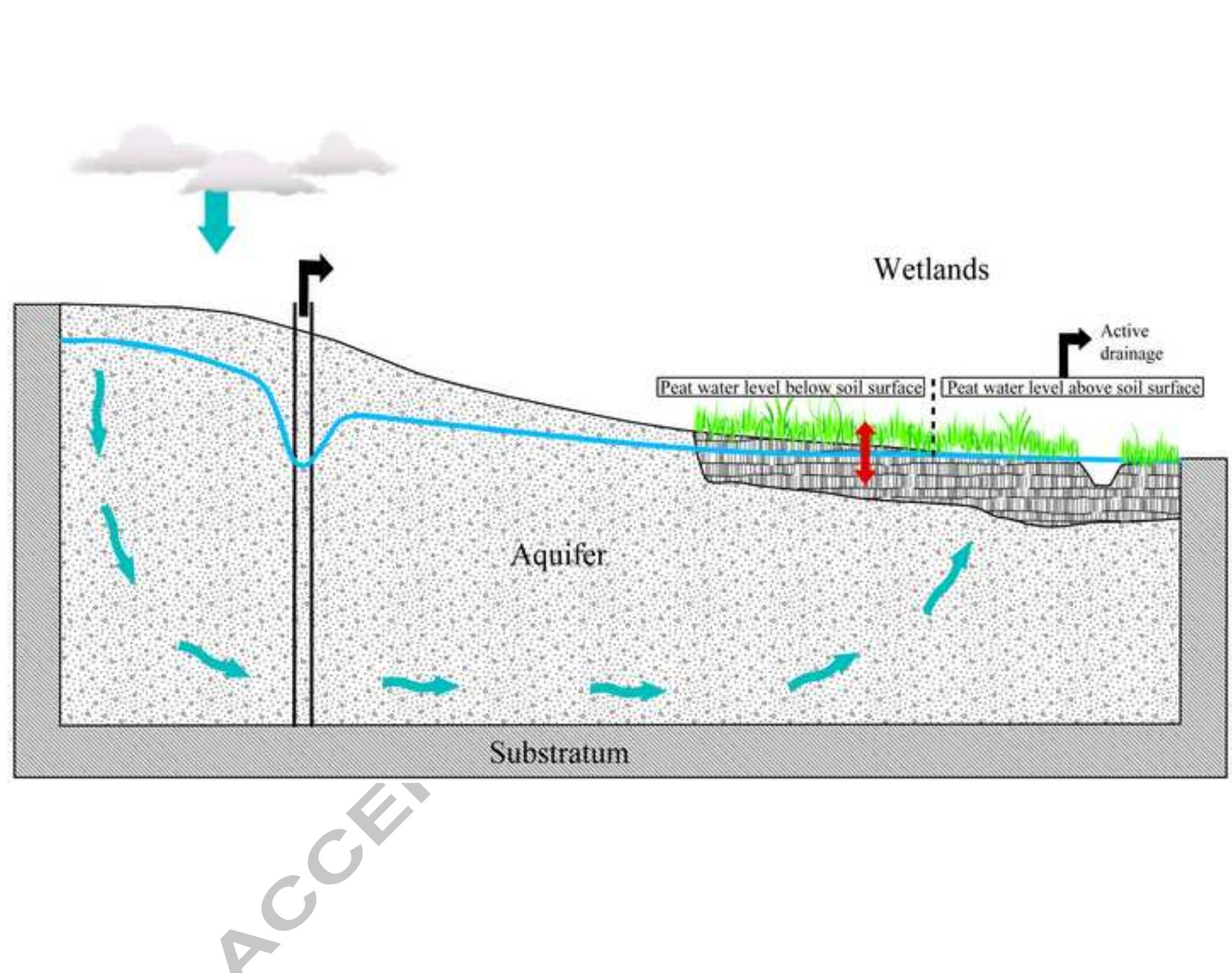

Substrat 


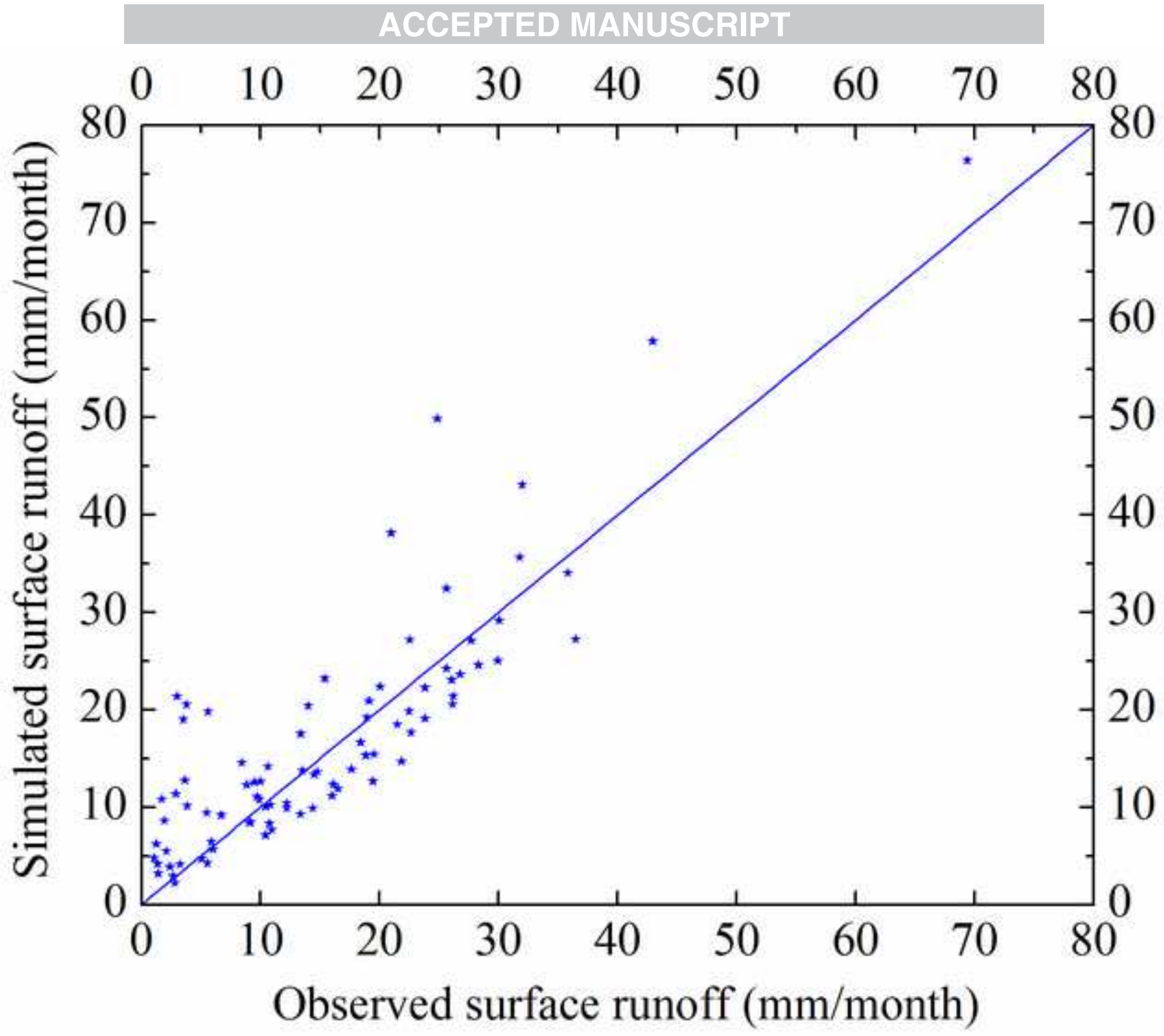


ACCEPTED MANUSCRIPT

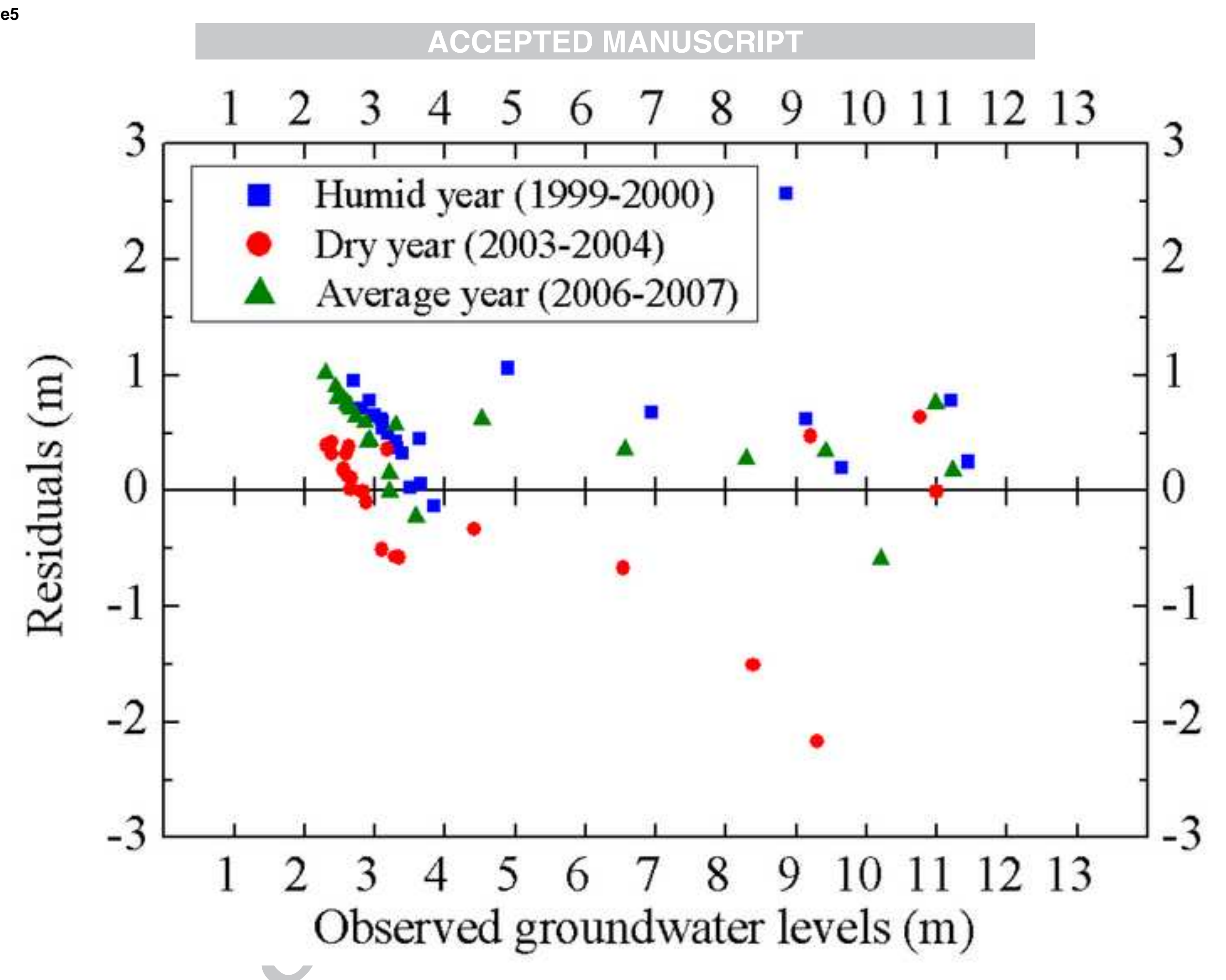


Wetlands observed (Cartography)
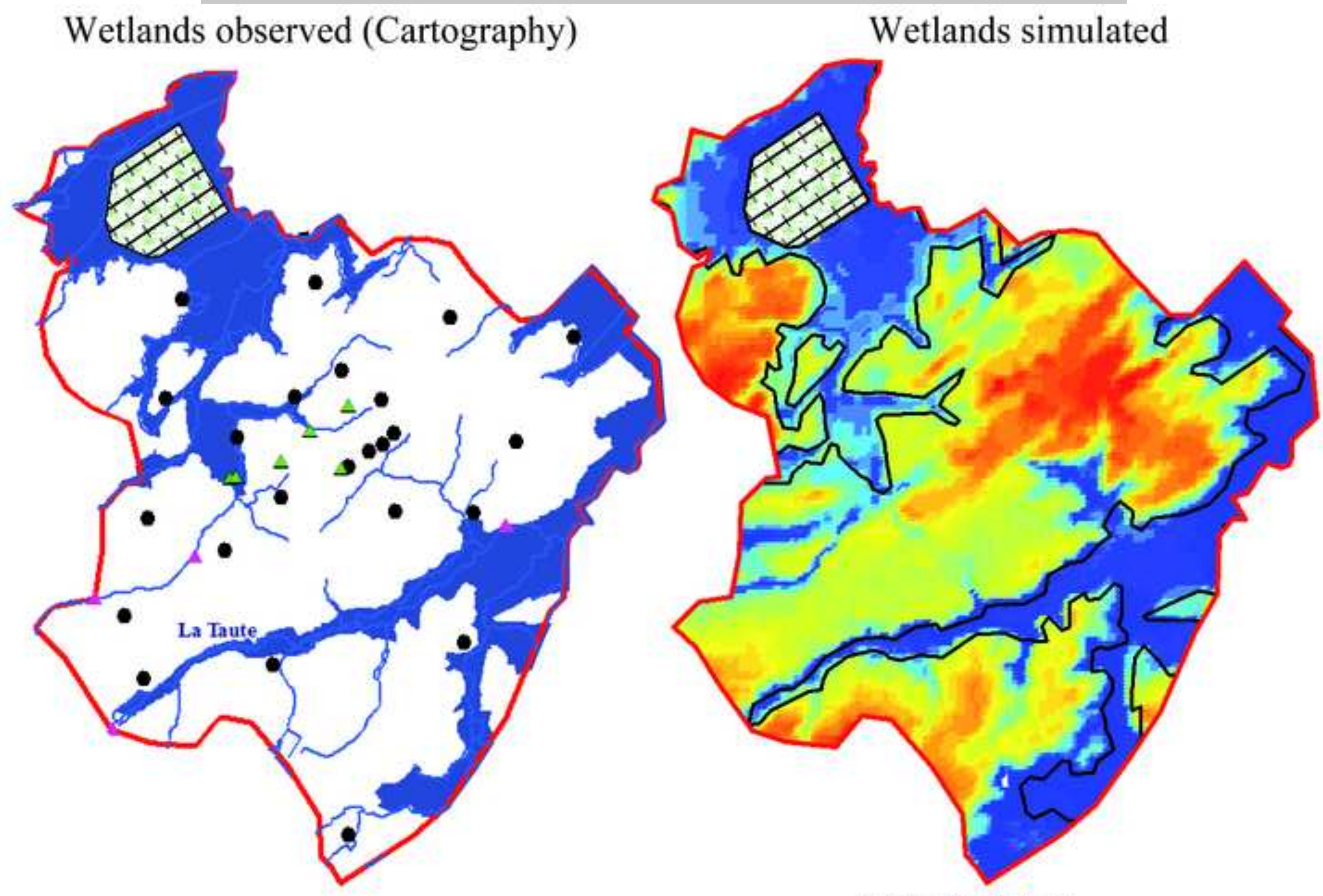

Water depth [m]

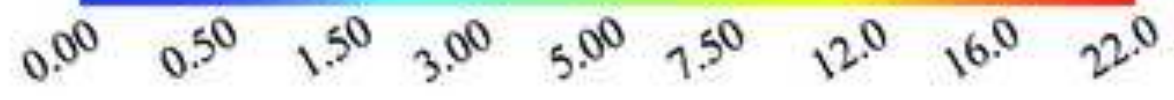



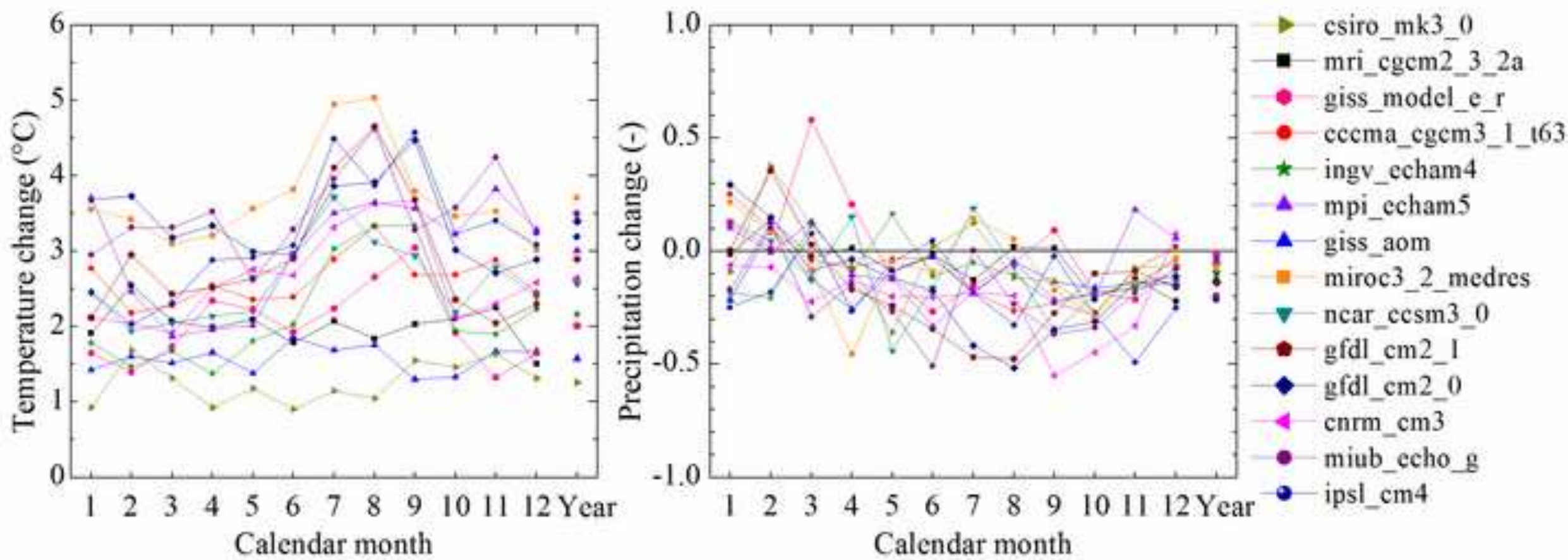


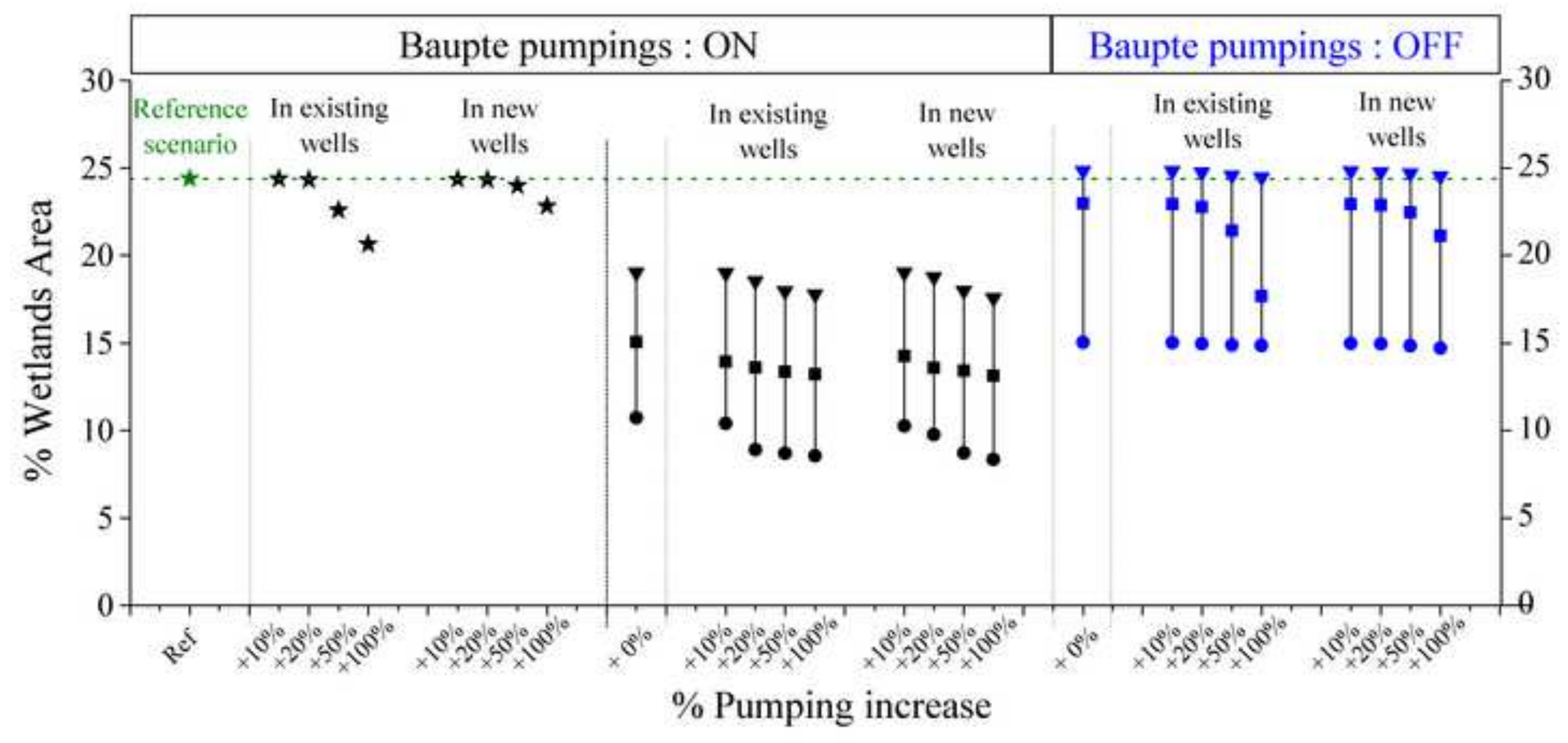

$\nabla$ Climate Scenario A $\checkmark$ Climate Scenario $\mathrm{H}$ o Climate Scenario N

... Line of current wetlands area (\%) s Scenario Reference 

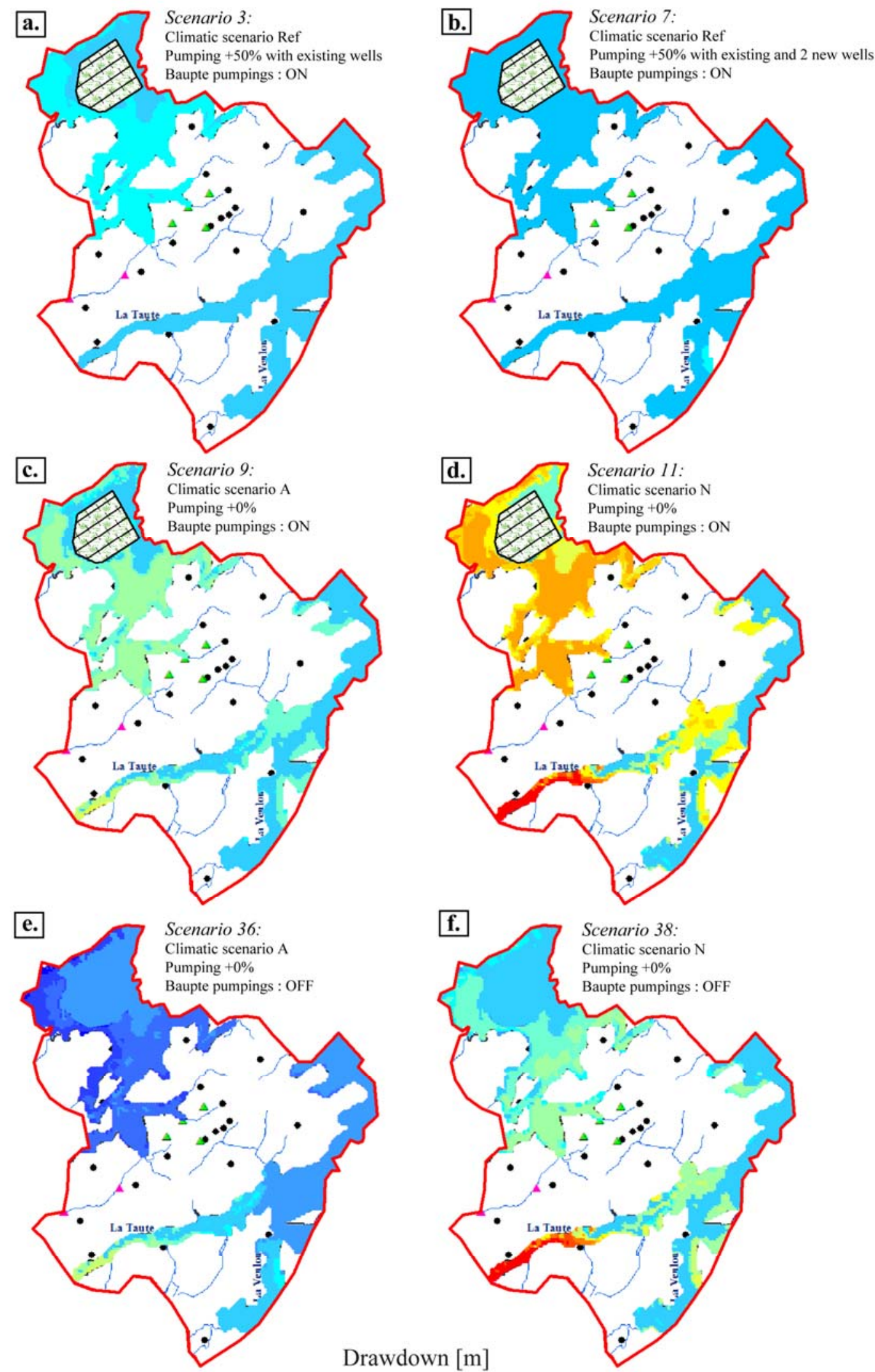

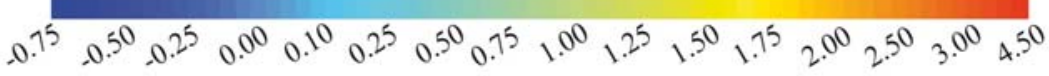




\begin{tabular}{|cccc|}
\hline Layer & Lithologie & $\mathbf{K}_{\mathbf{x y}}(\mathbf{m} / \mathbf{s})$ & $\mathbf{K}_{\mathbf{z}}(\mathbf{m} / \mathbf{s})$ \\
\hline \multirow{2}{*}{ Layer 1 } & Sands & $1 \times 10^{-6}$ & $1 \times 10^{-6}$ \\
& Peats & $8 \times 10^{-7}$ & $7 \times 10^{-8}$ \\
\hline & Shelly sands & $8 \times 10^{-3}$ & $8 \times 10^{-3}$ \\
Layer 2, 3, & Sandstones & $8 \times 10^{-4}$ & $8 \times 10^{-4}$ \\
$\mathbf{4 , 5 \text { and 6 }}$ & Sandy loams & $5.5 \times 10^{-6}$ & $5.5 \times 10^{-6}$ \\
& Sandy loams & $2 \times 10^{-5}$ & $2 \times 10^{-5}$ \\
\hline
\end{tabular}




\begin{tabular}{|c|c|c|c|c|c|c|}
\hline \multirow{3}{*}{$\begin{array}{l}\text { Increase of } \\
\text { groundwater } \\
\text { abstraction }\end{array}$} & \multirow{3}{*}{$\begin{array}{l}\text { Wells supporting } \\
\text { the groundwater } \\
\text { abstraction } \\
\text { increase }\end{array}$} & \multicolumn{4}{|c|}{ Climatic time slice and GCM } & \multirow{3}{*}{$\begin{array}{c}\text { Baupte } \\
\text { pumpings }\end{array}$} \\
\hline & & \multirow{2}{*}{ 1961-2000 } & \multicolumn{3}{|c|}{ 2081-2100 } & \\
\hline & & & $\mathbf{A}$ & $\mathbf{H}$ & $\mathbf{N}$ & \\
\hline $0 \%$ & & Ref & 9 & 10 & 11 & \multirow{9}{*}{$\mathrm{ON}$} \\
\hline $10 \%$ & & 1 & 12 & 13 & 14 & \\
\hline $20 \%$ & Existing & 2 & 15 & 16 & 17 & \\
\hline $50 \%$ & & 3 & 18 & 19 & 20 & \\
\hline $100 \%$ & & 4 & 21 & 22 & 23 & \\
\hline $10 \%$ & \multirow{4}{*}{ New } & 5 & 24 & 25 & 26 & \\
\hline $20 \%$ & & 6 & 27 & 28 & 29 & \\
\hline $50 \%$ & & 7 & 30 & 31 & 32 & \\
\hline $100 \%$ & & 8 & 33 & 34 & 35 & \\
\hline $0 \%$ & \multirow{5}{*}{ Existing } & & 36 & 37 & 38 & \multirow{9}{*}{ OFF } \\
\hline $10 \%$ & & & 39 & 40 & 41 & \\
\hline $20 \%$ & & & 42 & 43 & 44 & \\
\hline $50 \%$ & & & 45 & 46 & 47 & \\
\hline $100 \%$ & & & 48 & 49 & 50 & \\
\hline $10 \%$ & \multirow{4}{*}{ New } & & 51 & 52 & 53 & \\
\hline $20 \%$ & & & 54 & 55 & 56 & \\
\hline $50 \%$ & & & 57 & 58 & 59 & \\
\hline $100 \%$ & & & 60 & 61 & 62 & \\
\hline
\end{tabular}




\begin{tabular}{|cccc|}
\hline Scenario & Scenario name & $\begin{array}{c}\text { Calculated recharge } \\
(\mathbf{m m})\end{array}$ & $\begin{array}{c}\text { Calculated recharge } \\
\text { decrease by } \\
\mathbf{2 0 8 1} \mathbf{- 2 1 0 0}(\mathbf{\%})\end{array}$ \\
\hline Ref & Reference & 250 & 0 \\
\hline A & csri_mk3_0 & $\mathbf{1 9 4}$ & $\mathbf{2 2}$ \\
\hline B & mri_cgcm_3_2a & 182 & 27 \\
\hline C & giss_model_e_r & 182 & 27 \\
\hline D & ccma_cgcm3_1_t63 & 171 & 32 \\
\hline E & ingv_echam4 & 171 & 32 \\
\hline F & mpi_echam5 & 171 & 32 \\
\hline G & giss_aom & 163 & 35 \\
\hline H & miroc3_2_medres & $\mathbf{1 4 8}$ & $\mathbf{4 1}$ \\
\hline I & ncar_ccsm3_0 & 143 & 43 \\
\hline J & gfdl_cm2_1 & 137 & 45 \\
\hline K & gfdl_cm2_0 & 118 & 53 \\
\hline L & cnrm_cm3 & 110 & 56 \\
\hline M & miub_echo_g & 108 & 57 \\
\hline N & ipsl_cm4 & $\mathbf{9 7}$ & $\mathbf{6 1}$ \\
\hline
\end{tabular}




\begin{tabular}{|cc|c|c|c|c|}
\hline \multicolumn{2}{|c|}{ Climate Scenario } & Total influx & $\begin{array}{c}\text { Groundwater } \\
\text { discharge }\end{array}$ & Public wells & Baupte \\
\hline \multirow{2}{*}{ Reference (R=250 mm/yr) } & $\begin{array}{c}\text { m/yr of total } \\
\text { influx }\end{array}$ & $5.2 \mathrm{E}+07$ & $-3.7 \mathrm{E}+07$ & $-4.9 \mathrm{E}+06$ & $-1.0 \mathrm{E}+07$ \\
& 100 & -71.3 & -9.4 & -19.2 \\
\hline A (R=194 mm/yr) & \% of & 75 & -46.9 & -9.4 & -18.7 \\
H (R=148 mm/yr) & reference & 56 & -28.7 & -9.4 & -17.7 \\
N (R=97 mm/yr) & total influx & 38 & -12.1 & -9.4 & -16.2 \\
\hline A (R=194 mm/yr) & \% of total & 100 & -62.6 & -12.6 & -24.9 \\
H (R=148 mm/yr) & influx & 100 & -51.4 & -16.9 & -31.7 \\
N (R=97 mm/yr) & & 100 & -32.1 & -25.0 & -42.9 \\
\hline
\end{tabular}




\section{Highlights}

$727>$ Investigating impacts of climate change and groundwater pumping on wetland extension

$728>$ Simple model to understand surface-subsurface interaction and wetland vulnerability

$729>$ Climate change has a greater impact with loss of wetland area by 5.3 to $13.6 \%$

$730>$ The impact of groundwater abstraction would lead to a maximum decrease of $3.7 \%$

$731>$ Effects of climate and pumping could be reduced by stop pumping in peat exploitation 